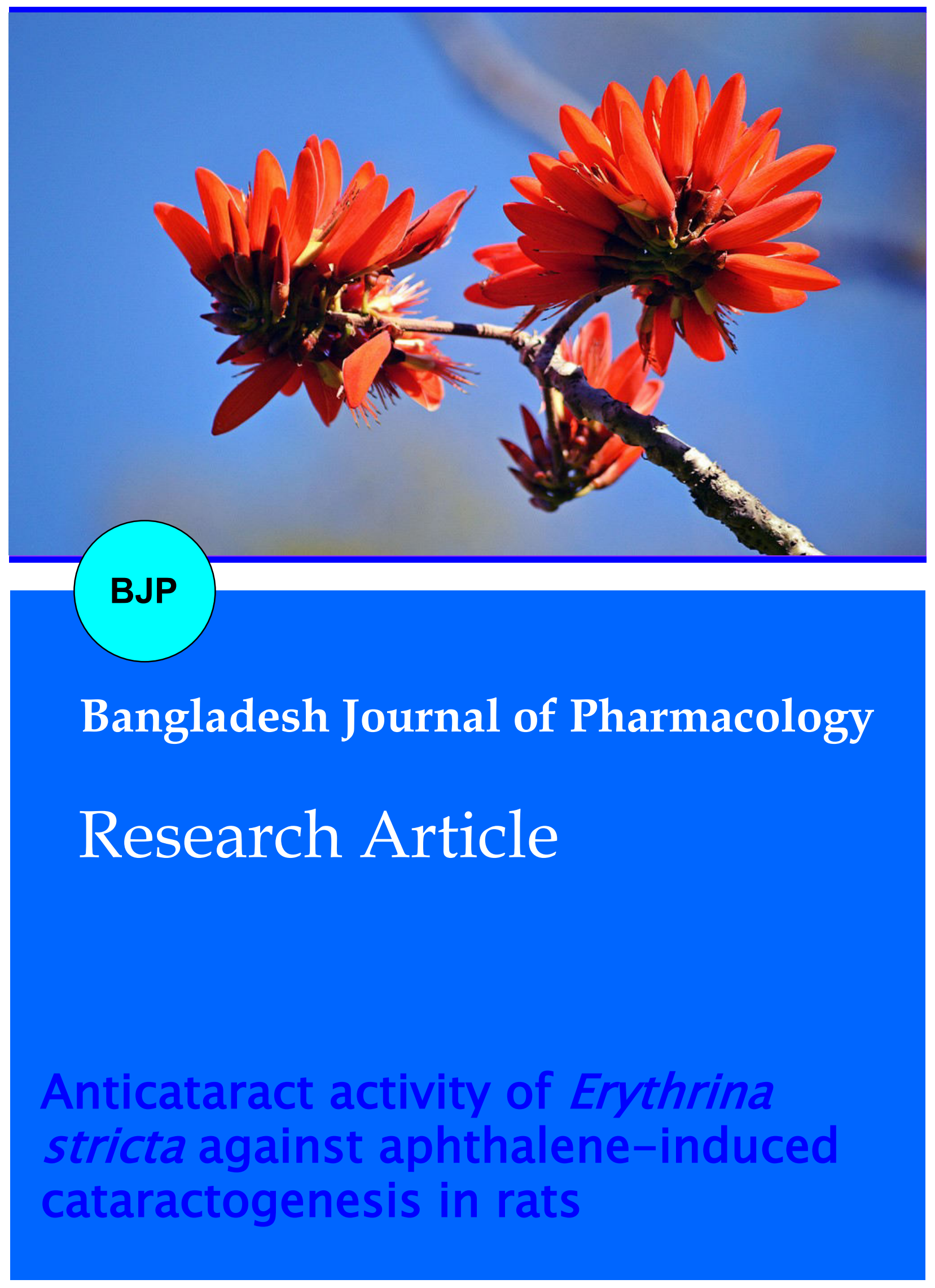




\section{Anticataract activity of Erythrina stricta against aphthalene-induced cataractogenesis in rats}

\section{Muthuswamy Umamaheswari, Kuppuswamy Asokkumar, Andichettiyar Thirumalaisamy Sivashanmugam, Varadharajan Subhadradevi and Michael Neethu}

\section{Department of Pharmacology, College of Pharmacy, Sri Ramakrishna Institute of Paramedical Sciences,} Coimbatore 641 044, Tamil Nadu, India.

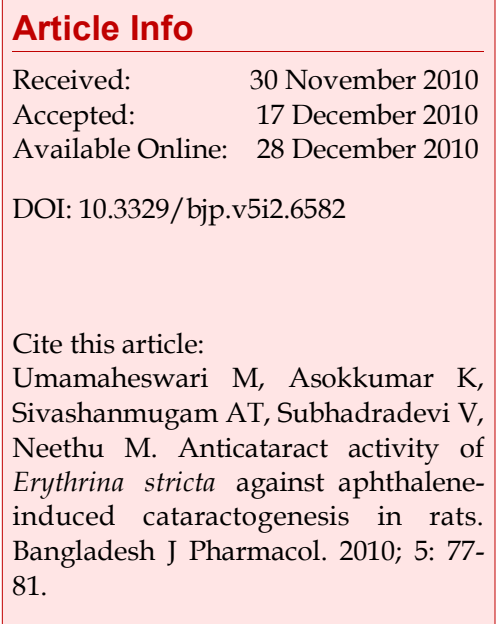

\begin{abstract}
The anticataract activity of Erythrina stricta leaves against naphthaleneinduced cataractogenesis was studied in Wistar albino rats. The various fractions of the leaf extract were administered orally $(200 \mathrm{mg} / \mathrm{kg})$ simultaneously with naphthalene $(1 \mathrm{~g} / \mathrm{kg})$ for 28 days. At the end of the experiment, levels of malondialdehyde, lipid hydroperoxides, carbonyl and sulfhydryl content, enzymatic and non-enzymatic anti-oxidants in lens homogenate were measured. Administration of naphthalene produced a mature cataract and an increase in the opacity index. There was a significant increase in lipid peroxidation and a decrease in anti-oxidant enzymes when compared to normal control. Ophthalmoscopic observation indicated that simultaneous administration of the fractions delayed the onset and maturation of cataract. All the fractions (except the residual fraction) prevented the peroxidative damage caused by naphthalene. The leaves of E. stricta protected the lens against naphthalene damage which may be due to its anti-oxidant activity.
\end{abstract}

\section{Introduction}

Cataract, a multifactorial disease occurs mainly due to the formation of large protein aggregates in the lens. Cataract remains the leading cause of visual disability and blindness all over the globe and the problem is more acute in the developing countries. Drugs have been developed which are aimed to interact at the level of altered lens metabolism and lens pathophysiology.

Erythrina stricta Roxb. belonging to the family Papilonaceae is a medium sized deciduous tree widely distributed in India. The leaves are reported to possess alkaloids such as erythraline, erysodine, erythrine and erysopine (Singh et al., 1981). The leaves of this species are used in Indian traditional medicine for the treatment of eye infections, ear ache, tooth ache, pain in the joints, skin eruptions, wounds, etc. (Kirtikar and Basu, 1981). Cataract formation in naphthalene-fed animals has been studied as a possible animal model for human senile cataracts. Hence, the objective of the present study is to investigate the effect of the fractions of E. stricta hydromethanolic leaf extract against naphthalene-induced cataractogenesis in rats.

\section{Materials and Methods}

\section{Experimental animals}

Wistar albino rats of either sex weighing between 125$150 \mathrm{~g}$ were used. They were housed in polypropylene cages inside a well-ventilated room. The room temperature was maintained at $23 \pm 2^{\circ} \mathrm{C}$ with a 12 hours light/dark cycle. Food and water were given ad libitum.

\section{Drugs and chemicals}

Naphthalene and vitamin E were obtained from SD fine chemicals, India. Liquid paraffin was obtained from Fisher Chemicals Ltd., Chennai, India. Thiobarbituric 
acid, butylated hydroxyl toluene, oxidized glutathione, epinephrine and 5 5'dithiobis-2- nitrobenzoic acid were obtained from Sisco Research Laboratories Pvt. Ltd., India. 2-2'-dipyridyl and O-dianisidine were obtained from Himedia Laboratories.

\section{Plant material}

The plant material consists of dried powdered leaves of E. stricta belonging to the family Papilionaceae. The leaves of E. stricta were collected from Kottayam district, Kerala, India during the month of April 2007. The plant was identified and authenticated by Mr. P. Sathyanarayana, Scientist, Botanical Survey of India, Tamil Nadu Agricultural University Campus, Coimbatore, Tamil Nadu, bearing the reference number BSI/SC/5/23/07-08/Tech-456.

\section{Preparation of extract and fractionation}

Fresh leaves of the plant were dried in shade under room temperature, powdered mechanically and sieved through No. 20 mesh sieve and extracted with methanol:water (7:3) and the hydromethanolic extract was partitioned separately against petroleum ether, chloroform and ethyl acetate in the order of increasing polarity. The petroleum ether (PEF), chloroform $(\mathrm{CF})$, ethyl acetate (EAF) and residual fractions (RF) of $E$. stricta were used for the study.

\section{Acute toxicity studies}

Swiss albino mice weighing between 20-30 g maintained under standard laboratory conditions was used. Animals were divided into four groups consisting of 5 each; the animals received a single oral dose $(2,000 \mathrm{mg} /$ $\mathrm{kg}$, body weight) of each fraction. Animals were kept overnight fasting prior to drug administration. After the administration of the fraction, food was withheld for further 3-4 hours. Animals were observed individually at least once during the first $30 \mathrm{~min}$ after dosing, periodically during the first 24 hours (with special attention during the first 4 hours) and daily thereafter for a period of 14 days.

\section{Selection of dose of the extract}

LD50 was done as per OECD guidelines for fixing the dose for biological evaluation (OECD, 2000). The LD50 of the fractions as per OECD guidelines falls under category 4 values with no signs of acute toxicity at doses of $2,000 \mathrm{mg} / \mathrm{kg}$. The biological evaluation of the fractions were carried out at a dose of $200 \mathrm{mg} / \mathrm{kg}$ body weight.

\section{Experimental protocol}

Animals were divided into 7 groups consisting of six animals each. Group I received liquid paraffin $(10 \mathrm{~mL} /$ $\mathrm{kg}$ orally) and served as control (Gupta, 2004). Group II received naphthalene $(1 \mathrm{gm} / \mathrm{kg}$ orally) alone (cataract control). Groups III-VI received the PEF, CF, EAF and
RF of E. stricta respectively at a dose of $200 \mathrm{mg} / \mathrm{kg}$ orally simultaneously with naphthalene. Group VII received vitamin $\mathrm{E}$ ( $50 \mathrm{mg} / \mathrm{kg}$ orally) with naphthalene (positive control). All the drugs were administered for a period of 28 days.

\section{Examination of eyes}

Eyes of the rats were examined daily by using ophthalmoscope for the morphological changes in the lens. Examination was performed after dilating the pupil with $1 \%$ tropicamide solution. The lens were examined and graded twice a week during the first two weeks and thereafter at weekly intervals (Sippel, 1966).

Cataract formation was scored according to different stages: Stage 1: clear normal lens; Stage 2: peripheral vesicles; Stage 3: peripheral vesicles and cortical opacities; Stage 4: diffuse central opacities; Stage 5: mature cataract. Cataract formation was considered complete (grade IV) when the red fundus reflex was no longer visible through any part of the lens and the lens appeared dull white to the naked eye (Fukushi et al., 1980).

$\%$ Incidence of cataract was calculated by:

$\%$ incidence $=\frac{\text { No. of animals in each stage }}{\text { Total no of animals }} \times 100$

Opacity index was calculated using the formula:

Opacity index $=$ No. of eyes in each stage $x$ Stage of the eye/Total No. of eye

\section{Preparation of the lens}

Immediately after blood collection, the rats were anesthetized and lenses were then dissected out, rinsed with ice cold saline. Each pair of lens was homogenized in a glass homogenizer with a teflon pestle in $1.2 \mathrm{~mL}$ of ice-cold phosphate buffer (20 mM, pH 7.4) and centrifuged and the supernatant was used for the analysis of total protein (Lowry et al., 1951) carbonyl and sulfhydryl determinations (Altomare et al., 1997), lipid peroxidation, hydroperoxide (Niehaus and Samuelsson, 1968), enzymatic and non-enzymatic antioxidant. Superoxide dismutase activity was determined by the inhibition of auto catalyzed adrenochrome formation in the presence of the homogenate at $480 \mathrm{~nm}$ (Kakkar et al., 1984). Catalase was estimated by the catalysis of $\mathrm{H} 2 \mathrm{O} 2$ to $\mathrm{H} 2 \mathrm{O}$ in an incubation mixture adjusted to $\mathrm{pH} 7.0$ was recorded at $254 \mathrm{~nm}$ (Sinha, 1972). Glutathione reductase activity was determined spectrophotometrically by the decrease in absorbance of NADPH at $340 \mathrm{~nm}$ (Racker, 1955). Glutathione peroxidase activity was measured by the procedure of Paglia and Valentine, 1967. Peroxidase activity was measured spectrophotometrically by following the change in absorbance at $460 \mathrm{~nm}$ due to O-dianisidine 
Table I

Effect of the fractions of Erythrina stricta incidence $(\%)$ of cataract on $28^{\text {th }}$ day

\begin{tabular}{|c|c|c|c|c|c|}
\hline \multirow[t]{2}{*}{ Group } & \multicolumn{5}{|c|}{ Incidence of cataract (\%) } \\
\hline & $\begin{array}{c}\text { Stage } \\
1\end{array}$ & $\begin{array}{l}\text { Stage } \\
2\end{array}$ & $\begin{array}{c}\text { Stage } \\
3\end{array}$ & $\begin{array}{c}\text { Stage } \\
4\end{array}$ & $\begin{array}{l}\text { Stage } \\
5\end{array}$ \\
\hline Normal saline & 100 & 0 & 0 & 0 & 0 \\
\hline $\begin{array}{l}\text { Naphthalene } \\
\text { control }\end{array}$ & 0 & 0 & 0 & 66.7 & $\begin{array}{r}33 . \\
3\end{array}$ \\
\hline $\begin{array}{l}\text { Petroleum ether } \\
\text { fraction }\end{array}$ & 0 & 33.3 & 33.3 & 33.3 & 0 \\
\hline $\begin{array}{l}\text { Chloroform } \\
\text { fraction }\end{array}$ & 16.7 & 50 & 33.3 & 0 & 0 \\
\hline $\begin{array}{l}\text { Ethyl acetate } \\
\text { fraction }\end{array}$ & 0 & 33.3 & 33.3 & 16.7 & $\begin{array}{r}16 . \\
7\end{array}$ \\
\hline $\begin{array}{l}\text { Residual frac- } \\
\text { tion }\end{array}$ & 0 & 0 & 16.7 & 66.7 & $\begin{array}{r}16 . \\
7\end{array}$ \\
\hline Vitamin E & 33.3 & 50 & 16.7 & 0 & 0 \\
\hline
\end{tabular}

Table II

Effect of the fractions of Erythrina stricta on opaci-ty index in control and experimental animals Group Opacity index

\begin{tabular}{|lrrrr|}
\cline { 2 - 5 } & Day 7 & Day 14 & Day 21 & Day 28 \\
\hline Normal saline & 1 & 1 & 1 & 1 \\
$\begin{array}{l}\text { Naphthalene con- } \\
\text { trol }\end{array}$ & 2.2 & 3.0 & 3.7 & 4.2 \\
$\begin{array}{l}\text { Petroleum ether } \\
\text { fraction }\end{array}$ & 1.5 & 2.0 & 2.3 & 3.0 \\
$\begin{array}{l}\text { Chloroform frac- } \\
\text { tion }\end{array}$ & 1.2 & 1.3 & 2.0 & 2.2 \\
$\begin{array}{l}\text { Ethyl acetate frac- } \\
\text { tion }\end{array}$ & 1.7 & 2.0 & 2.3 & 3.2 \\
$\begin{array}{l}\text { Residual fraction } \\
\text { Vitamin E }\end{array}$ & 2.2 & 2.3 & 3.2 & 3.8 \\
\hline
\end{tabular}

oxidation in the presence of $\mathrm{H}_{2} \mathrm{O}_{2}$ and enzyme (Lobarzewski and Ginalska, 1995). The estimation of nonenzymatic anti-oxidant reduced glutathione was based on the reaction of reduced glutathione with dithionitrobenzoic acid to give a compound that absorbs at $412 \mathrm{~nm}$ (Ellman, 1959).

\section{Statistical analysis}

Statistical analysis was carried out by one-way analysis of variance (ANOVA) followed by Dunnett's test. Results are expressed as mean \pm SEM from six rats in each group. $P$ values $<0.05$ were considered significant.

\section{Results}

In acute toxicity studies, it was found that the animals were safe up to a maximum dose of $2,000 \mathrm{mg} / \mathrm{kg}$ body weight. There were no changes in normal behavioral pattern and no signs and symptoms of toxicity and mortality were observed.

Staging of cataract and opacity index is given in Table I and II respectively. Ophthalmoscopic examination of the eyes showed that the lenses of normal control were in stage 1 throughout the duration of experimental period. Animals treated with naphthalene showed varying degree of cataractogenic changes as evidenced by about $66.6 \%$ of animals in stage 4 and $33.3 \%$ in stage 5 mature cataract on $28^{\text {th }}$ day of treatment. None of the animals in the PEF and CF-treated groups showed mature stage 5 cataract on $28^{\text {th }}$ day. Treatment with the EAF showed $16.6 \%$ of animals in both stage 4 and stage 5 cataract, whereas the RF showed $66.6 \%$ in stage 4 and $16.6 \%$ in stage 5 mature cataract. Treatment with the standard drug, vitamin E showed $16.6 \%$ of animals in stage 3 and there was no diffuse central opacities (stage 4) and mature cataract (stage 5). Treatment with naphthalene showed an increase in the opacity index from 2.2 on the $7^{\text {th }}$ day, 3.7 on the $21^{\text {st }}$ day followed by complete opacification (opacity index 4.2 ) on the $28^{\text {th }}$ day. The groups treated with PEF, CF and EAF of E. stricta showed a decrease in opacity index (3.0, 2.2, 3.2 respectively) when compared to naphthalene control. The incidence of cataract in residual fraction treated group was slightly lower (3.8) in comparison to naphthalene control. There was a marked reduction in the opacity index (1.8) of the vitamin E treated group when compared to the fractions.

There was a significant $(p<0.01)$ decrease in the level of total protein and an increase in the level of malondialdehyde and lipid hydroperoxide in the lens of naphthalene treated animals when compared to normal control. Treatment with PEF, CF and EAF of $E$. stricta and vitamin $\mathrm{E}$ simultaneously with naphthalene for 28 days caused a significant $(\mathrm{p}<0.01)$ decrease in the malondialdehyde, lipid hydroperoxide and an increase in total protein content. The effect produced by the RF on protein concentration and $\mathrm{LH}$ is insignificant $(p>0.05)$ whereas the decrease in MDA was significant $(p<0.05)$ compared to naphthalene control (Table III).

Treatment with naphthalene led to a significant $(p<0.01)$ increase in the free carbonyl groups of lens proteins as measured by the absorbance of DNPH bound to total lens protein. At the end of the experiment, significantly higher values of free carbonyls were observed in the lenses of naphthalene treated rats when compared to healthy controls. An increase in DNPH-reactive carbonyls was accompanied by significant $(p<0.01)$ decrease in sulfhydryl content titrable by DNPH. Treatment with pet ether, chloroform, ethyl acetate fractions of E. stricta and Vitamin E significantly ( $p<0.01$ ) decreased the carbonyl content and increased the sufhydryl content similar to the vitamin E-treated groups. The decrease in carbonyl 


\begin{tabular}{|c|c|c|c|c|}
\hline \multicolumn{5}{|c|}{ Table III } \\
\hline \multicolumn{5}{|c|}{$\begin{array}{c}\text { Effect of the fractions of Erythrina stricta on serum uric acid, protein, malondialdehyde and lipid } \\
\text { hydroperoxide }\end{array}$} \\
\hline Group & Dose (per oral) & $\begin{array}{l}\text { Malondialdehyde } \\
\text { (nmoles/min/mg pro- } \\
\text { tein) }\end{array}$ & $\begin{array}{l}\text { Lipid hydroperoxide } \\
\text { (nmoles/min/mg pro- } \\
\text { tein) }\end{array}$ & $\begin{array}{l}\text { Protein } \\
\text { (mmoles/min/mg wet } \\
\text { tissue) }\end{array}$ \\
\hline Normal saline & $10 \mathrm{~mL} / \mathrm{kg}$ & $0.6 \pm 0.1$ & $0.6 \pm 0.1$ & $1833.3 \pm 0.92$ \\
\hline Naphthalene control & $1 \mathrm{~g} / \mathrm{kg}$ & $1.9 \pm 2.7^{a}$ & $2.0 \pm 0.1^{\mathrm{a}}$ & $226.9 \pm 17^{a}$ \\
\hline Petroleum ether fraction & $200 \mathrm{mg} / \mathrm{kg}$ & $0.9 \pm 0.1^{b}$ & $0.9 \pm 0.8^{c}$ & $1555.3 \pm 150^{b}$ \\
\hline Chloroform fraction & $200 \mathrm{mg} / \mathrm{kg}$ & $0.9 \pm 0.0^{\mathrm{b}}$ & $0.8 \pm 0.0^{\mathrm{b}}$ & $1653.7 \pm 500^{b}$ \\
\hline Ethyl acetate fraction & $200 \mathrm{mg} / \mathrm{kg}$ & $0.9 \pm 0.0^{b}$ & $1.2 \pm 0.0^{c}$ & $852.6 \pm 50.6^{c}$ \\
\hline Residual fraction & $200 \mathrm{mg} / \mathrm{kg}$ & $1.0 \pm 0.0^{\mathrm{b}}$ & $1.2 \pm 0.1^{\mathrm{d}}$ & $539.5 \pm 33.6^{d}$ \\
\hline Vitamin E & $50 \mathrm{mg} / \mathrm{kg}$ & $0.6 \pm 0.1^{b}$ & $0.6 \pm 0.1^{b}$ & $1512.4 \pm 200^{b}$ \\
\hline
\end{tabular}

\begin{tabular}{|c|c|c|c|}
\hline \multicolumn{4}{|c|}{ Table IV } \\
\hline \multicolumn{4}{|c|}{ After RAA treatment } \\
\hline Group & $\begin{array}{l}\text { Dose } \\
\text { (orally) }\end{array}$ & $\begin{array}{c}\text { Carbonyl } \\
\text { content } \\
\text { (nmoles/mg } \\
\text { protein) }\end{array}$ & $\begin{array}{c}\text { Sulfhydryl } \\
\text { content } \\
\text { (nmoles/mg } \\
\text { protein) }\end{array}$ \\
\hline $\begin{array}{l}\text { Normal sa- } \\
\text { line }\end{array}$ & $10 \mathrm{~mL} / \mathrm{kg}$ & $0.7 \pm 0.0$ & $78.4 \pm 2.7$ \\
\hline $\begin{array}{l}\text { Naphthalene } \\
\text { control }\end{array}$ & $1 \mathrm{~g} / \mathrm{kg}$ & $2.0 \pm 0.3^{a}$ & $45.3 \pm 2.2^{\mathrm{a}}$ \\
\hline $\begin{array}{l}\text { Petroleum } \\
\text { ether fraction }\end{array}$ & $200 \mathrm{mg} / \mathrm{kg}$ & $1.0 \pm 0.1^{b}$ & $64.7 \pm 1.9 \mathrm{~b}$ \\
\hline $\begin{array}{l}\text { Chloroform } \\
\text { fraction }\end{array}$ & $200 \mathrm{mg} / \mathrm{kg}$ & $0.6 \pm 0.1^{b}$ & $68.7 \pm 1.3^{b}$ \\
\hline $\begin{array}{l}\text { Ethyl acetate } \\
\text { fraction }\end{array}$ & $200 \mathrm{mg} / \mathrm{kg}$ & $1.1 \pm 0.1^{b}$ & $60.0 \pm 0.9 b$ \\
\hline $\begin{array}{l}\text { Residual } \\
\text { fraction }\end{array}$ & $200 \mathrm{mg} / \mathrm{kg}$ & $1.7 \pm 0.1^{c}$ & $50.9 \pm 0.9 c$ \\
\hline Vitamin E & $50 \mathrm{mg} / \mathrm{kg}$ & $0.8 \pm 0.0^{\mathrm{b}}$ & $71.2 \pm 1.8^{\mathrm{b}}$ \\
\hline
\end{tabular}

and sulfhydryl contents produced by the residual fraction was insignificant $(p>0.05)$ when compared to naphthalene control (Table IV).

Treatment with naphthalene for 28 days produced a significant $(p<0.01)$ decrease in the enzymatic antioxidants like catalase, superoxide dismutase, peroxidase, glutathione peroxidase, glutathione reductase and the non-enzymatic anti-oxidant, reduced glutathione when compared to normal control. Treatment with the fractions of E. stricta (except the residual fraction) significantly $(p<0.01)$ restored the levels of both enzymatic and non enzymatic anti-oxidant enzymes which is almost similar to the control group. The activity produced by the standard vitamin $\mathrm{E}$ was found to be the highest among the groups tested (Table V).

\section{Discussion}

In this studies, naphthalene-treated animals showed an increase in malondialdehyde and lipid hydroperoxide levels in serum and lens. Treatment with the PEF, CF and EAF of E. stricta simultaneously with naphthalene for 28 days caused a significant decrease in the serum uric acid and lens malondialdehyde, lipid hydroperoxide and an increase in total protein level.

Free carbonyls and sulfhydryls were used as markers of oxidative modifications of lens proteins. In course of cataract development, we observed an increase in the protein carbonyl content and a decrease in the concentration of protein sulfhydryl in lenses with the advanced stage of naphthalene-induced cataract when compared with the lenses of normal control. Treatment with the fractions of E. stricta (except residual fraction) has significantly decreased the carbonyl content and increased the sulfhydryl content compared to control.

The fractions of E. stricta significantly increased the catalase level in naphthalene-induced cataractogenesis. SOD and GPx has a major role in degrading the levels of $\mathrm{H}_{2} \mathrm{O}_{2}$ in cells. GPx, GSSH, SOD, and peroxidase levels in naphthalene treated groups were decreased when compared to normal control group. The chloroform fraction of E. stricta significantly increased the level of anti-oxidant enzymes such as GPx, GSSH, peroxidase and SOD. PEF significantly increased the level of GPx, GSSH, peroxidase and also significantly increased the level of SOD. Similarly the ethyl acetate fraction significantly increased the levels of GPx and GSSH when compared to napthalene treated rats. GSH is widely distributed in cells. It protects the cells against free radicals, peroxides and other toxic compounds (Vani and Rawal, 1966). All the fractions of E. stricta significantly increased the level of GSH when compared to naphthalene treated rats. 


\section{Table V}

Effect of the fractions of Erythrina stricta on tissue enzymatic and non-enzymatic anti-oxidants

\begin{tabular}{|c|c|c|c|c|c|c|c|}
\hline Group & Dose & Catalase & GPx & SOD & GSSH & Peroxidase & GSH \\
\hline Normal saline & $10 \mathrm{~mL} / \mathrm{kg}$ & $28.0 \pm 1.6$ & $183.2 \pm 0.1$ & $28.7 \pm 0.8$ & $32.6 \pm 1.1$ & $27.5 \pm 1.0$ & $70.5 \pm 5.2$ \\
\hline Naphthalene control & $1 \mathrm{~g} / \mathrm{kg}$ & $10.6 \pm 0.8^{a}$ & $113.1 \pm 3.8^{a}$ & $9.9 \pm 0.6^{a}$ & $15.1 \pm 1.4^{a}$ & $13.0 \pm 1.01^{\mathrm{a}}$ & $25.1 \pm 1.3^{a}$ \\
\hline $\begin{array}{l}\text { Petroleum ether frac- } \\
\text { tion }\end{array}$ & $200 \mathrm{mg} / \mathrm{kg}$ & $21.0 \pm 2.6^{b}$ & $153.3 \pm 10 c$ & $18.8 \pm 1.0^{\mathrm{b}}$ & $25.8 \pm 1.5^{\mathrm{b}}$ & $15.9 \pm 0.6^{c}$ & $37.0 \pm 1.0^{b}$ \\
\hline Chloroform fraction & $200 \mathrm{mg} / \mathrm{kg}$ & $24.8 \pm 3.1^{b}$ & $165.9 \pm 20^{b}$ & $21.9 \pm 2.4^{b}$ & $27.7 \pm 1.5^{b}$ & $20.8 \pm 1.0^{\mathrm{b}}$ & $61.3 \pm 3.2^{b}$ \\
\hline Ethyl acetate fraction & $200 \mathrm{mg} / \mathrm{kg}$ & $35.0 \pm 0.0 c$ & $146.7 \pm 3.4 \mathrm{c}$ & $17.0 \pm 0.0^{\mathrm{b}}$ & $22.4 \pm 0.9 c$ & $14.4 \pm 0.4^{c}$ & $36.5 \pm 2.1^{b}$ \\
\hline Residual fraction & $200 \mathrm{mg} / \mathrm{kg}$ & $12.0 \pm 0.6^{\mathrm{d}}$ & $125.8 \pm 3.1^{\mathrm{d}}$ & $11.0 \pm 0.7 \mathrm{~d}$ & $18.5 \pm 1.6^{\mathrm{d}}$ & $10.3 \pm 0.6^{\mathrm{d}}$ & $28.2 \pm 1.0^{\circ}$ \\
\hline Vitamin E & $50 \mathrm{mg} / \mathrm{kg}$ & $26.4 \pm 2.3^{b}$ & $178.2 \pm 21.5^{b}$ & $26.7 \pm 2.3^{b}$ & $31.1 \pm 0.9 b$ & $22.2 \pm 0.8^{b}$ & $69.5 \pm 2.2^{b}$ \\
\hline
\end{tabular}

\section{Conclusion}

The study suggested that the leaves of E. stricta possess anticataract and anti-oxidant activities, which might be helpful in preventing or slowing the progress of cataract.

\section{References}

Altomare E, Grattagliano I, Vendemaile G, Micelli-Ferrari T, Signorile A, Cardia L. Oxidative protein damage in human diabetic eye: Evidence for retinal participation. Eur J Clin Invest. 1997; 27: 141-47.

Ellman GL. Tissue sulphydryl groups. Arch Biochem Biophys. 1959; 82: 70-77.

Fukushi S, Merola LO, Kinoshita JH. Altering the course of cataracts in diabetic rats. Invest Ophthalmol Vis Sci. 1980; 19: 313-15.

Gupta SK. Drug screening methods. 1st ed. New Delhi, Jaypee Brothers, 2004, pp 333-46.

Kakkar P, Das B, Viswanathan PN. A modified spectrophotometric assay of superoxide dismutase. Indian J Biochem Biophys. 1984; 21: 130-32.

Kirtikar KR, Basu RD. Indian medicinal plants. 2nd ed. International Book Distributors, Dehradun, 1981, pp 781-83.

Lobarzewski J, Ginalska G. Industrial use of soluble or immobilized plant peroxidases. Plant Perox News Lett. 1995; 6: 37.
Lowry OH, Rosebrough NJ, Farr AL, Randall RJ. Protein measurement with the Folin phenol reagent. J Biol Chem. 1951; 193: 265-75.

Niehaus WG Jr, Samuelsson B. Formation of malondialdehyde from phospholipid arachidonate during microsomal lipid peroxidation. Eur J Biochem. 1968; 6: 126-30.

OECD. Acute oral toxicity-acute oral toxic class method. Guideline 423, adopted 17.12.2001. In: Thirteenth Addendum to the OECD Guidelines for the testing of chemicals. Paris: Organization for economic co-operation and development, 2000.

Paglia DE, Valentine WN. Studies on the quantitative and qualitative characterization of erythrocyte glutathione peroxidase. J Lab Clin Med. 1967; 70: 158-69.

Racker E. Glutathione reductase from bakers' yeast and beef liver. J Biol Chem. 1955; 217: 855-65.

Singh H, Chawla AS, Kapoor VK, Kumar N, Piatak DM, Nowicki W. Investigation of Erythrina Spp. IX. Chemical Constituents of Erythrina stricta Bark. J Nat Prod. 1981; 44: 526-29.

Sinha AK. Colorimetric assay of catalase. Anal Biochem. 1972; 47: 389-94.

Sippel TO. Changes in the water, protein and glutathione contents of the lens in the course of galactose cataract development in rats. Invest Opthalmol. 1966; 5: 568-75.

Vani RR, Rawal UM. Glutathione and glutathione redox cycle in riboflavin supplemented cataractous rat lenses. Indian J Pharmacol. 1966; 28: 93-97. 